\title{
Diabetic ketosis and coma
}

\author{
D. A. PYKE \\ From the Diabetic Department, King's College Hospital, London
}

This paper is a review of selected aspects of ketosis and coma in diabetes. The two terms are not synonymous and indeed part of this review is concerned with distinguishing between them. Diabetic coma is defined here as depression or loss of consciousness due to uncontrolled diabetes whether or not associated with severe ketosis.

\section{KETOSIS}

Ketosis is of crucial importance in the management of diabetic patients. The presence of significant amounts of ketone bodies in the urine is usually an indication of the need for insulin and is the best single chemical guide to the type of treatment a patient needs. However, some patients show an appreciable ketonuria at diagnosis which nevertheless subsides on simple treatment and does not reappear. If the patient's clinical condition warrants it, therefore, it is often justifiable to delay the use of insulin since such treatment, once started, tends to be continued, and the fact that insulin is not essential may never be appreciated.

About $40 \%$ of diabetics attending clinics in Britain need insulin, judging from our experience at King's College Hospital. This may be a slight overestimate of the average figure, as there is a high proportion of young patients in our clinic. Certainly only a minority of diabetics need insulin to prevent serious ketosis; the rest are at little risk of going into precoma or coma, even in the presence of infection.

The assessment of ketosis, so important in clinical management, has hitherto depended largely on urine tests. Modern enzyme tests are highly sensitive and specific. The simpler chemical tests, such as Acetest tablets ${ }^{1}$ or Ketostix strips ${ }^{1}$ are sensitive to about 5 to $10 \mathrm{mg} / 100 \mathrm{ml}$ of aceto-acetic acid; they are much less sensitive to acetone, but this is in any case a minor component.

Measurement of ketones in plasma has until recently not been very satisfactory, though an adaptation of Rothera's test has been known for many years and more recently Acetest tablets have been

\footnotetext{
${ }^{1}$ Ames Company, Division of Miles Laboratories, Stoke Poges, Bucks.
}

used for rough estimates of plasma aceto-acetate concentration. The enzyme method of Williamson, Mellanby, and Krebs (1962) is much more satisfactory than the older methods and has permitted accurate measurement of aceto-acetate and $\beta$-hydroxybutyrate in blood at low concentrations. Williams, Berry, Taylor, and Pyke (unpublished observations) have used this method to determine fasting plasma ketone levels in untreated diabetics, established diabetics, and in apparently healthy nondiabetics. The results are given in Tables I and II. There was no correlation of the plasma ketone values with age or sex.

TABLE I

MEAN FASTING PLASMA KETONE LEVELS

$\begin{array}{llll}\begin{array}{l}\text { Aceto- } \\ \text { acetate }\end{array} & \begin{array}{l}\beta-O H- \\ \text { butyrate } \\ (\mu M)\end{array} & \text { Total } & \begin{array}{l}\text { Ratio } \\ \text { BHB }: A A\end{array}\end{array}$

\begin{tabular}{|c|c|c|c|c|}
\hline $\begin{array}{l}\text { Normal controls (23) } \\
\text { Obese }(>10 \% \\
\text { overweight) }\end{array}$ & $\begin{array}{l}21 \\
15\end{array}$ & $\begin{array}{l}42 \\
33\end{array}$ & $\begin{array}{l}63 \pm \\
48 \pm\end{array}$ & $\begin{array}{ll}7 & 2.7 \pm 0.4 \\
8 & 2.2 \pm 0.2\end{array}$ \\
\hline $\begin{array}{l}\text { Aketonuric } \\
\text { diabetics } \\
\text { (new cases) }\end{array}$ & 82 & 269 & $351 \pm$ & $553.8 \pm 0.8$ \\
\hline
\end{tabular}

TABLE II

\begin{tabular}{llccc} 
MEAN FASTING & PLASMA & $\begin{array}{l}\text { KETONE } \\
\text { Aceto- }\end{array}$ & $\begin{array}{c}\text { LEVELS IN } \\
\beta-O H-\end{array}$ & DIABETICS \\
$\begin{array}{l}\text { Degree of } \\
\text { Ketonuria }\end{array}$ & $\begin{array}{l}\text { Number } \\
\text { of Cases }\end{array}$ & $\begin{array}{l}\text { acetate } \\
(\mu M)\end{array}$ & $\begin{array}{l}\text { Total } \\
(\mu M)\end{array}$ \\
\hline None & 21 & 82 & 269 & 351 \\
Mild & 5 & 297 & 1,042 & 1,339 \\
Considerable & 2 & 780 & 3,011 & 3,791 \\
In coma & 1 & 2,127 & 7,509 & 9,636
\end{tabular}

The values agree closely with those reported by Bergmeyer and Bernt (1965), who also used an enzymatic method, but are substantially lower than the values reported by Werk and Knowles (1961) and Johnson, Sargent, and Passmore (1958) using chemical methods. The ratio of $\beta$-hydroxybutyrate to aceto-acetate in normals $(2.7: 1)$ was similar to that reported by Williamson et al (1962). In the obese subjects the mean was slightly but not significantly lower than in normal subjects.

In the diabetics without ketonuria the mean 
plasma value was over five times that of normal subjects. There appeared to be no correlation between the degree of ketonaemia and the blood glucose levels. The ratio of $\beta$-hydroxybutyrate to aceto-acetate was not significantly different from that found in normal subjects, but it was significantly higher than in the obese subjects.

In the diabetics with ketonuria blood ketone levels were much higher (Table II); in those with mild ketonuria the mean total value was 20 times normal and in the two patients with considerable ketonuria it was 60 times the normal value. In the one patient who was in diabetic coma the value was over 150 times normal.

This general correlation between the ketone levels in blood and urine did not apply in every case; for instance, two patients without ketonuria had blood levels as high as those with ketonuria.

These results confirm that urine tests for acetoacetate provide a rough guide to the degree of ketonaemia. They also show that there is hyperketonaemia in nearly all newly diagnosed diabetics, for only one of the 21 cases had a normal blood ketone value. This degree of hyperketonaemia does not, however, signify a tendency to clinical ketosis as we ordinarily understand that term, since none of the 21 patients needed insulin treatment in a twoyear follow-up period.

Recently a simpler and quicker micro-method for measuring plasma aceto-acetate on the AutoAnalyzer has been described by Salway and his colleagues (personal communication). After dialysis the plasma aceto-acetate reacts with 2:5-dichlorobenzene diazonium chloride to produce a yellow product which is measured photometrically. By this method the normal fasting aceto-acetate level is less than 100 $\mu \mathrm{M}$ (Watkins and FitzGerald, personal communication). In a large number of diabetics $80 \%$ of the values were in the normal range, about $14 \%$ were between 100 and $200 \mu \mathrm{M}$, and $6 \%$ were raised to over $200 \mu \mathrm{M}$. As might be expected, patients with uncontrolled diabetes had high blood ketone values, but so did other patients whose diabetes appeared to be well controlled and who did not show ketonuria. A few patients with very high blood sugar values nevertheless had low ketone levels. Thus this study too showed poor correlation between blood sugar and blood ketone levels.

This simple technique of plasma ketone measurement has enabled serial observations to be made on patients throughout the 24 hours. In a well controlled patient on oral antidiabetic therapy the plasma aceto-acetate may remain in the normal range, but in a patient on insulin with considerable swings of blood sugar level the ketone level also swings; in the early morning with a rising blood sugar level, high ketone values are also found but as the blood sugar declines after insulin injection, so does the ketone level.

Frequent blood ketone measurement has also amplified the old observation that hypoglycaemia leads to ketonuria by showing that plasma ketones also are increased. A fall of blood glucose to less than about $50 \mathrm{mg} / 100 \mathrm{ml}$ regularly leads to an increase in ketonaemia, sometimes with ketonuria. The mechanism of increased hepatic ketogenesis in response to hypoglycaemia is unknown. Hypoglycaemia causes an increase in the secretion of growth hormone and of catecholamines, both of which are ketogenic, but the effect of hypoglycaemia in producing ketonuria is not abolished by hypophysectomy or adrenalectomy. However, sympathectomy does impair ketogenesis in pancreatectomized dogs (Houssay, Rietti, Ashkar, Del Castillo, Galli, Roldan, and Urgoiti, 1967), and $\beta$-adrenergic blockade with propranol is known to inhibit the lipolytic effect of hypoglycaemia, so it is possible that the effect of hypoglycaemia is mediated by the sympathetic nervous system. Alternatively the effect may be due simply to decreased peripheral glucose uptake as a direct result of the low blood sugar.

Since starvation, vomiting, and hypoglycaemia can each lead to increased ketonaemia and ketonuria, the significance of the latter must be assessed critically when used in the control of diabetes.

These two studies show then that there are considerable variations in ketonaemia in diabetes. In our study of newly diagnosed cases raised levels were very common, though in cases of established diabetes reported by Watkins and FitzGerald (personal communication) they were found in only a minority. However the level of ketonaemia in both series was well below that found in patients suffering from clinical ill-effects of ketosis, ie, in precoma or coma.

\section{DIABETIC COMA}

Diabetic precoma and coma have a characteristic age and sex incidence. They occur especially in juvenile-onset diabetics, though the patients are not necessarily young when they are admitted in coma. In a series of 100 consecutive admissions half the patients were aged over $\mathbf{4 0}$ and about one fifth were over 60. Age has great relevance to the prognosis, which is considerably worse in patients over 60 years than in those below this age. Most studies show that admission for severe ketosis is commoner in females than in males at all ages, especially in adolescence when emotional crises are an important contributory cause.

Diabetic coma remains a common and important hazard. Among 3,438 patients attending the Diabetic 
Department at King's College Hospital, one in every seven had at some time been admitted to hospital on that account (Table III).

\section{TABLE III}

PERCENTAGE OF 3,438 DIABETICS EVER ADMITTED TO HOSPITAL IN DIABETIC PRECOMA OR COMA ACCORDING TO SEX AND AGE AT DIAGNOSIS (OAKLEY, PYKe, AND TAYLOR, 1968)

\begin{tabular}{lrr} 
Age at Diagnosis & Male & Female \\
\hline Less than 30 years & 31 & 39 \\
$30-50$ years & 5 & 16 \\
50 years and over & 2 & 3 \\
Whole group & 12 & 16
\end{tabular}

The cause of severe diabetic ketosis, though not always detectable, is usually one of the following: (1) omission or reduction of insulin, usually on the patient's initiative; (2) undiagnosed diabetes; (3) vomiting from any cause; (4) infection.

If a patient, usually an adolescent, reduces or stops insulin when emotionally disturbed or in order to gain attention, the consequent deterioration may be very rapid and the patient may pass into precoma within 12 hours.
The biochemical changes in precoma and coma are well known. In our series of 100 consecutive cases the mean blood sugar was $736 \mathrm{mg} / 100 \mathrm{ml}$ (Oakley, Pyke, and Taylor, 1968). Plasma ketone levels also are greatly raised (Watkins and FitzGerald, 1968 ); in 14 cases levels of plasma $\beta$-hydroxybutyrate ranged from 3,900 to $18,000 \mu \mathrm{M}$ with a mean of $10,000 \mu \mathrm{M}$. This is an increase of at least 100 -fold over normal levels, and we have ourselves found an increase of 150 fold in a single case (Table I).

As a result of ketoacidosis there is a fall in $p \mathrm{H}$, and levels as low as 6.89 have been recorded with recovery. In six patients showing a strongly positive Ketostix reaction the mean $p \mathrm{H}$ was 7.07 and in eight less severely ketotic patients the figure was $7 \cdot 20$ (Watkins and FitzGerald, 1968). Plasma bicarbonate concentration is greatly reduced and has been used by some physicians as the criterion by which the severity of the 'coma' is assessed. However, the correlation between bicarbonate and severity of illness is poor and plasma bicarbonate concentration is not a reliable prognostic guide.

Dehydration and electrolyte losses are severe. Our knowledge of their extent starts from the classic

TABLE IV

SUMMARY OF DATA FROM FIVE REPORTED CASES OF CEREBRAL OEDEMA CAUSING DEATH IN DIABETIC COMA

\begin{tabular}{|c|c|c|c|c|c|c|c|c|c|c|c|c|}
\hline \multirow{2}{*}{$\begin{array}{l}\text { Case } \\
\text { No. }\end{array}$} & \multirow{2}{*}{ Series } & \multirow{2}{*}{$\begin{array}{l}\text { Patient's } \\
\text { Age } \\
\text { and Sex }\end{array}$} & \multirow[b]{2}{*}{$\begin{array}{l}\text { Interval } \\
\text { since } \\
\text { Diagnosis } \\
\text { of Diabetes } \\
\text { (years) }\end{array}$} & \multirow[b]{2}{*}{$\begin{array}{l}\text { Blood Sugar } \\
\text { on } \\
\text { Admission } \\
\text { ( }(\mathrm{mg} / 100 \mathrm{ml})\end{array}$} & \multirow[b]{2}{*}{$\begin{array}{l}\text { Plasma } \\
\text { Bicarbonate } \\
\text { (m-equiv/ } \\
\text { litre) }\end{array}$} & \multirow[b]{2}{*}{$\begin{array}{l}\text { Clinical } \\
\text { State }\end{array}$} & \multicolumn{2}{|c|}{$\begin{array}{l}\text { Treatment } \\
\text { before Onset } \\
\text { of Coma }\end{array}$} & \multicolumn{2}{|c|}{$\begin{array}{l}\text { Hours before } \\
\text { Onset of }\end{array}$} & \multicolumn{2}{|c|}{$\begin{array}{l}\text { Blood Chemistry } \\
\text { at Onset } \\
\text { of Coma }\end{array}$} \\
\hline & & & & & & & $\begin{array}{l}\text { Insulin } \\
(u)\end{array}$ & $\begin{array}{l}\text { Intravenous } \\
\text { Fluids } \\
\text { (litres) }\end{array}$ & Coma & Death & $\begin{array}{l}\text { Sugar } \\
(m g / 100 \\
m l)\end{array}$ & $\begin{array}{l}\text { Electrolytes } \\
\text { (m-equiv/l) }\end{array}$ \\
\hline 1 & $\begin{array}{l}\text { FitzGerald } \\
\text { O'Sullivan } \\
\text { and Malins } \\
\text { (1961) }\end{array}$ & $13 \mathrm{~F}$ & 0 & 530 & & Drowsy & $\begin{array}{l}120 \\
\text { in } 2 \mathrm{hrs}\end{array}$ & 2 & 10 & 10 & $\begin{array}{l}260 \\
\text { at } 6 \mathrm{hrs}\end{array}$ & \\
\hline 2 & Ibid. & $15 \mathrm{M}$ & 0 & 540 & & $\begin{array}{l}\text { Fully } \\
\text { conscious, } \\
\text { air } \\
\text { hunger } \\
\text { slight }\end{array}$ & 80 & $\begin{array}{l}\text { Oral } \\
\text { fluids }\end{array}$ & 6 & 36 & 288 & $\begin{array}{l}\mathrm{Na} .130 \\
\mathrm{~K} .5 \cdot 3 \\
\mathrm{HCO}_{3} 12 \cdot 1\end{array}$ \\
\hline 4 & $\begin{array}{l}\text { Young } \\
\text { and } \\
\text { Bradley } \\
(1967)\end{array}$ & $14 \mathrm{~F}$ & 5 & 640 & & Drowsy & $\begin{array}{l}80 \\
\text { in } 1 \mathrm{st} \\
3 \mathrm{hrs}\end{array}$ & 4 & $\begin{array}{l}\text { Gra- } \\
\text { dual } \\
\text { from } \\
3 \mathrm{hrs} \\
\text { com- } \\
\text { plete by } \\
12 \mathrm{hrs}\end{array}$ & $\begin{array}{l}168 \\
\text { by }\end{array}$ & $\begin{array}{l}360 \\
\text { at } 4 \mathrm{hrs} \\
148 \\
\text { at } 11 \mathrm{hrs}\end{array}$ & $\begin{array}{l}\mathrm{Na} .142 \\
\mathrm{~K} .4 \cdot 5 \\
\mathrm{Cl} .110 \\
\mathrm{HCO} 13 \\
\text { at } 8-10 \mathrm{hrs}\end{array}$ \\
\hline 5 & Ibid. & $9 \mathrm{M}$ & $7 \frac{1}{2}$ & 580 & 11 & $\begin{array}{l}\text { Semi- } \\
\text { comatose }\end{array}$ & 110 & 1 & 6 & 28 & $\begin{array}{l}120 \\
\text { at } \\
8 \mathrm{hrs}\end{array}$ & $\begin{array}{l}\mathrm{HCO}_{3} 7 \\
\text { at } 8 \mathrm{hrs} \\
\mathrm{Na} .153 \\
\mathrm{~K} .3 \cdot 1 \\
\mathrm{HCO}, 11 \\
\text { at } 11 \mathrm{hrs}\end{array}$ \\
\hline
\end{tabular}


work of Atchley, Loeb, Richards, Benedict, and Driscoll (1933), who measured with extreme thoroughness the water and electrolyte losses in patients who were allowed to pass into precoma. An easier, safer and equally elegant approach was that of Nabarro, Spencer, and Stowers (1952) who measured the water, electrolyte, and nitrogen balances of 10 patients as they were recovering from severe diabetic ketosis.

We have measured plasma insulin values in five of our patients in coma and found them to be 9 to $33 \mu \mathrm{u} / \mathrm{ml}$. This is within the normal fasting range but is very low in relation to blood glucose levels of 275 to $500 \mathrm{mg} / 100 \mathrm{ml}$.

The contribution of circulating insulin antagonists to diabetic coma is uncertain. Whereas claims for an $\alpha$,-globulin antagonist have been refuted, it is known that corticosteroid levels in the blood are increased (Nabarro, 1965); moreover ketone bodies and fatty acids are themselves insulin antagonists.

The blood urea level is commonly raised, but rarely exceeds $100 \mathrm{mg} / 100 \mathrm{ml}$ and usually returns to normal within two to three days. A high and rising blood urea level is a poor prognostic sign.

Serum uric acid may be increased because of diminished excretion, but the level returns to normal within 24 to 48 hours of the start of treatment.

Polymorphonuclear leucocytosis is common, and does not necessarily indicate infection.

\section{CEREBRAL OEDEMA}

A rare but difficult problem is posed by recently described cases of sudden or rapid death in young patients apparently recovering from diabetic ketoacidosis. At least five patients have been reported with several features in common (Table IV). The patients were children aged 9 to 16 in whom the diagnosis of diabetic precoma was made on the usual grounds, and none of the five was actually unconscious on admission. In such patients one would not expect any mortality, and these, whose blood sugar on admission was 530 to $640 \mathrm{mg} / 100 \mathrm{ml}$, seemed to respond well initially to treatment. However, they lost consciousness, suddenly in most cases, at six to 12 hours after the start of treatment when blood glucose and electrolyte values were improving. In case 2 sudden loss of consciousness occurred in a patient whose illness was so relatively mild that he had been able to take fluids by mouth. In case 3 diabetes insipidus developed immediately after the sudden loss of consciousness.

Postmortem examination revealed severe cerebral oedema with congestion and neuronal atrophy. In the case with diaketes insipidus there was necrosis of the hypothalamus and midbrain. Microscopy showed oedema, leucocytic infiltration, focal haemorrhages, and degeneration or necrosis of nerve cells.

The mechanism of this acute cerebral oedema is unknown. The fact that it appears during recovery from severe ketoacidosis suggests that it might be due to treatment, perhaps resulting from overhydration or a reversed blood-brain glucose gradient due to a rapidly falling blood sugar level. Neither of these explanations is satisfactory. The syndrome has appeared in cases where no excess of sodiumcontaining fluid seems to have been given and in one instance (case 2) consciousness was lost after six hours when only oral fluids had been given, and when the serum sodium concentration was 130 m-equiv/ 1 and the blood sugar $288 \mathrm{mg} / 100 \mathrm{ml}$. The condition is unlikely to be the result of a reversal of the blood-brain glucose gradient because cerebral oedema does not seem to develop in patients dying from diabetic coma without ketoacidosis (see below) where the blood sugar has been brought down rapidly from very high levels.

Alternatively the oedema may be the direct result of the diabetic ketoacidosis, leading via dehydration, acidosis, and ketosis to decreased cerebral blood flow, tissue anoxia, cerebral cellular damage, and oedema, but again this is an unlikely cause in cases as mild as case 2 .

The coma does not respond to treatment for cerebral oedema. In cases 4 and 5 intravenous mannitol and steroids were given without apparent effect. This may have been because they were administered too late in the course of the illness, irreversible brain damage having already occurred. However when mannitol is given for prolonged coma due to severe hypoglycaemia it seems to be rapidly effective, recovery of consciousness occurring within three quarters of an hour in two patients (Hoffbrand and Sevitt, 1966); in such cases the coma is presumed to be due to cerebral oedema.

Very recently cerebral oedema associated with hyperglycaemia has been produced experimentally in animals (Clements, Prockop, and Winegrad, 1968). Seven healthy fasting dogs under barbiturate anaesthesia were given an intravenous infusion of glucose to raise their blood glucose rapidly to 400 to $500 \mathrm{mg} / 100 \mathrm{ml}$ and maintain it at that level for four hours. Isotonic saline was then infused for another four hours. Measurements of cerebrospinal fluid pressure were made throughout. During the phase of glucose infusion CSF pressure fell; but when saline was substituted the pressure gradually rose and in six of the dogs it rose well above the normal range by the end of the experiment. The rise did not occur if, after glucose infusion, the animals were not 
rehydrated with saline. These results showed (1) that increased CSF pressure was not the result of the hyperglycaemia but of its treatment and (2) that the CSF pressure could be raised in this way to pathologically high values.

It is known that glucose can be reversibly converted to sorbitol and thence to fructose, and in a second series of experiments the same authors measured CSF glucose, fructose, and sorbitol during the two phases of glucose and saline infusion. Cerebrospinal fluid glucose rose, although to a lesser extent and more slowly than plasma glucose. At the end of the first four hours the mean CSF level was approximately $200 \mathrm{mg} / 100 \mathrm{ml}$, less than half that of plasma. When the infusion was switched to saline, CSF glucose fell more slowly than plasma levels, and one to two hours after the start of the saline infusion the level of CSF glucose was actually higher than that of plasma glucose.

Fructose and sorbitol levels in the CSF also rose during the phase of glucose infusion, and during the saline infusion the levels of both actually increased during the first two hours but then slowly fell. Clements et al suggest that the cerebral 'oedema' may be due to increased intracellular concentrations of sorbitol in the brain. Sorbitol does not cross the cell membrane readily, and is osmotically active; at a time when the glucose level, and hence the osmotic concentration, of the plasma and CSF is falling, a raised sorbitol level in the brain cells could set up a reverse osmotic gradient with cellular overhydration and swelling of the brain. Whatever the explanation we now have experimental evidence of cerebral oedema developing during the rehydration phase after hyperglycaemia. There is as yet no explanation of the rarity of cerebral oedema in the treatment of diabetic coma.

\section{DIABETIC COMA WITHOUT KETOSIS}

This syndrome, which has recently attracted increasing attention, has also been called aketotic diabetic coma, hyperosmolar coma, and hyperosmolar hypernatraemic coma. None of these terms is entirely satisfactory because some ketosis is present in this type of coma, because hypernatraemia is not a constant feature, and because typical ketoacidotic coma is also hyperosmolar.

Although it is only in the last decade that many papers have appeared on diabetic coma without ketoacidosis, a description of the condition was first given nearly a century ago (Dreschfeld, 1886). Recently reviews of published cases have appeared by Schwartz and Apfelbaum (1965-66) and by Oakley et al (1968).

The condition consists of drowsiness or unconsciousness, with dehydration but without hyperventilation; blood analysis shows hyperglycaemia but only slight acidosis and ketosis. An arbitrary plasma bicarbonate level of more than $15 \mathrm{~m}$-equiv/1 has been used in the definition of the syndrome and we have followed this practice; in ketoacidotic coma lower levels are usual.

The condition, previously regarded as a rarity, now seems to be relatively common. In a series of 122 consecutive emergency admissions for 'diabetic coma' to King's College Hospital analysed by $\mathrm{Dr}$ T. C. Harvey, $13(11 \%)$ were cases of diabetic coma without ketoacidosis of whom seven were West Indians. The West Indians have been considered as a separate group. The whole series (Table V) includes seven Jamaicans, one of whom was admitted on three occasions, and 93 white patients, of whom 23 were new diabetics presenting in coma, and 70 were established diabetics who were admitted on 90 occasions.

There are some obvious biochemical differences between Jamaicans and the other two groups, for blood sugar and urea, plasma bicarbonate and osmolality are all higher on average in the Jamaicans. The difference in blood sugar is considerable; among the Jamaicans the mean level was nearly 1,000 $\mathrm{mg} / 100 \mathrm{ml}$, a figure reached by only one tenth of the English patients. In none of the Jamaicans was the plasma bicarbonate level below $15 \mathrm{~m}$-equiv/1 whereas figures below this level were found in twothirds of the cases in the other two groups. The mean blood urea among the Jamaicans was nearly

TABLE V

DIABETIC COMA IN THREE CLINICAL GROUPS

\begin{tabular}{|c|c|c|c|c|c|c|c|c|}
\hline & \multicolumn{2}{|l|}{ Numbers } & \multirow{2}{*}{$\begin{array}{l}\text { Mean } \\
\text { Age }\end{array}$} & \multicolumn{4}{|c|}{ Mean Blood or Plasma Levels } & \multirow{2}{*}{$\begin{array}{l}\text { Mean } \\
\text {-Plasma } \\
\text { Osmolarity } \\
(m-o s m / l)\end{array}$} \\
\hline & Patients & Admissions & & $\begin{array}{l}\text { Sugar } \\
(\mathrm{mg} / 100 \mathrm{ml})\end{array}$ & $\begin{array}{l}\mathrm{Na} \\
\text { (m-equiv } / l)\end{array}$ & $\begin{array}{l}\mathrm{HCO}_{3} \\
(m \text {-equiv/l) }\end{array}$ & $\begin{array}{l}\text { Urea } \\
(\mathrm{mg} / 100 \mathrm{ml})\end{array}$ & \\
\hline $\begin{array}{l}\text { Jamaicans } \\
\text { New diabetics } \\
\text { Established diabetics }\end{array}$ & $\begin{array}{r}7 \\
23 \\
70\end{array}$ & $\begin{array}{r}9 \\
23 \\
90\end{array}$ & $\begin{array}{l}39 \\
34 \\
41\end{array}$ & $\begin{array}{l}958 \\
672 \\
627\end{array}$ & $\begin{array}{l}143 \\
136 \\
130\end{array}$ & $\begin{array}{r}18 \cdot 5 \\
12 \cdot 3 \\
8 \cdot 9\end{array}$ & $\begin{array}{r}130 \\
74 \\
76\end{array}$ & $\begin{array}{l}372 \\
332 \\
318\end{array}$ \\
\hline Total & 100 & 122 & & & & & & \\
\hline
\end{tabular}

${ }^{1}$ Calculated from chemical analyses. 
double that in the other groups and the calculated osmolality was also higher.

These differences in the biochemical findings were reflected in differences in the clinical pictures. All the Jamaicans were cases of diabetic coma without ketoacidosis, whereas only six out of the other two groups were considered to belong to this category. Table VI shows an analysis of these 13 cases, together with three others to make a total of $16 .{ }^{1}$ All but one of these patients was a new diabetic. Their which is about 13 times the normal level but much lower than in typical ketoacidotic coma.

Two of these 16 patients were studied in some detail by Dr D. M. Hill and Dr I. D. Ramsey as part of a cooperative study of this type of diabetic coma (Tables VII and VIII).

CASE 1 (KCH 245389) was a man aged 68, not previously known to be diabetic. After symptoms for one month he was admitted in precoma. The blood sugar was very high but the plasma ketones were little raised. Blood $p \mathrm{H}$ was

TABLE VI

16 CASES OF DIABETIC COMA WITHOUT KETOACIDOSIS ${ }^{1}$

\begin{tabular}{|c|c|c|c|c|c|c|c|c|c|c|c|c|}
\hline \multirow{2}{*}{$\frac{\operatorname{Sex}}{M}$} & \multirow{2}{*}{$F$} & \multirow{2}{*}{$\begin{array}{l}\text { West } \\
\text { Indian }\end{array}$} & \multirow[t]{2}{*}{ English } & \multirow{2}{*}{$\begin{array}{l}\text { Mean Blood } \\
\text { Sugar } \\
(m g \%)\end{array}$} & \multirow{2}{*}{$\begin{array}{l}\text { Mean } \\
\text { Plasma Na } \\
(m \text {-equiv/l) }\end{array}$} & \multirow{2}{*}{$\begin{array}{l}\text { Plasma } K \\
(m-e q u i v / l)\end{array}$} & \multirow{2}{*}{$\begin{array}{l}\text { Plasma } \\
\mathrm{HCO}_{3} \\
(m \text {-equiv } / l)\end{array}$} & \multirow{2}{*}{$\begin{array}{l}\text { Blood } \\
\text { Urea } \\
(m g \%)\end{array}$} & \multirow{2}{*}{$\begin{array}{l}\text { Plasma } \\
\text { Osmolality } \\
(m-o s m / l)\end{array}$} & \multicolumn{3}{|c|}{ Treatment } \\
\hline & & & & & & & & & & Diet & $\begin{array}{l}\text { Diet and } \\
\text { Tablets }\end{array}$ & $\begin{array}{l}\text { Diet and } \\
\text { Insulin }\end{array}$ \\
\hline 5 & 11 & 8 & 8 & $\begin{array}{l}1,040 \\
(340-2,500)\end{array}$ & $\begin{array}{l}140 \\
(109-155)\end{array}$ & $\begin{array}{l}5 \cdot 1 \\
(3 \cdot 8-6 \cdot 8)\end{array}$ & $\begin{array}{l}19 \cdot 7 \\
(15-27)\end{array}$ & $\begin{array}{l}116 \\
(50-230)\end{array}$ & $\begin{array}{l}368 \\
(326-425)\end{array}$ & 4 & 4 & 7 \\
\hline
\end{tabular}

${ }^{1}$ There was one death in the series.

main features are similar to those of 55 published cases reviewed by Oakley et al (1968). The mean age of the 16 patients was greater than that of patients with typical ketoacidotic coma. It has generally been reported that diabetic coma without ketoacidosis occurs mainly in middle age, but it has recently been recorded in a child aged 18 months (Ehrlich and Bain, 1967).

Clinically these patients were drowsy and ill and even more dehydrated than is usual in diabetic coma, but they were not overbreathing, the breath did not smell of acetone, and urine tests for ketones were negative or only weakly positive. In one girl aged 10 the severe dehydration led to very striking lens changes, giving an appearance of dense cataract, which disappeared rapidly on treatment (Oakley et al, 1968).

Although we speak of coma 'without ketoacidosis' the level of ketones in the blood is above normal. In the 10-year-old girl mentioned above total serum aceto-acetate and $\beta$-hydroxybutyrate was $810 \mu \mathrm{M}$

${ }^{1}$ One of these 16 cases, the 10-year-old girl, was included in the 55 cases reviewed by Oakley et al (1968). normal, as were the plasma lactate and electrolyte values, but blood urea and plasma osmolality were raised. Serum immunoreactive insulin was $25 \mu \mathrm{u} / \mathrm{ml}$ which, though normal for the fasting state, is very low for such a high blood glucose level. Plasma cortisol was not raised $(14 \mu \mathrm{g} / 100 \mathrm{ml})$.

\section{TABLE VIII}

TREATMENT AND RESULTS IN TWO CASES OF DIABETIC COMA WITHOUT KETOACIDOSIS

\begin{tabular}{lccc} 
Case & $\begin{array}{l}\text { Insulin } \\
(\text { units })\end{array}$ & $\begin{array}{l}\text { Fluid Balance } \\
(\mathrm{ml})\end{array}$ & $\begin{array}{l}\text { Na Balance } \\
(\text { m-equiv) }\end{array}$ \\
\hline 1 First 12 hrs & 120 & $+4,880$ & +485 \\
Second 12 hrs & 32 & $+1,250$ & +48 \\
Total & 152 & $+6,130$ & +533 \\
& & & +422 \\
First 12 hrs & 132 & $+2,100$ & +32 \\
Second 12 hrs & 44 & $+1,420$ & +454 \\
Total & 176 & $+3,520$ &
\end{tabular}

CASE 2 (KCH 255001) was a woman of 64 with a history of thirst and polyuria for about six months. On admission she was semiconscious and very dehydrated. Blood sugar was very high but blood ketones were only slightly raised,

TABLE VII

FINDINGS IN TWO CASES OF DIABETIC COMA WITHOUT KETOACIDOSIS

\begin{tabular}{|c|c|c|c|c|c|c|c|c|c|}
\hline $\begin{array}{l}\text { Case } \\
\text { No. }\end{array}$ & $\begin{array}{l}\text { Time } \\
(h r)\end{array}$ & $\begin{array}{l}\text { Blood } \\
\text { Glucose } \\
(\mathrm{mg} / 100 \mathrm{ml})\end{array}$ & $\begin{array}{l}\text { Plasma } \\
\text { Ketostix } \\
\text { Reaction }\end{array}$ & $\begin{array}{l}\text { Blood } \\
\text { pH }\end{array}$ & $\begin{array}{l}\text { Plasma } \\
\mathrm{HCO}_{3} \\
(\mathrm{~m} \text {-equiv/l) }\end{array}$ & $\begin{array}{l}\text { Blood } \\
\text { Urea } \\
(\mathrm{mg} / 100 \mathrm{ml})\end{array}$ & $\begin{array}{l}\text { Serum } \\
\text { Insulin } \\
(\mu u / m l)\end{array}$ & $\begin{array}{l}\text { Plasma } \\
\text { Osmolarity } \\
(m-o s m / l)\end{array}$ & $\begin{array}{l}\text { Plasma } \\
\text { FFA } \\
(\boldsymbol{m} \text {-osm/ } \mathrm{\mu M})\end{array}$ \\
\hline 1 & $\begin{array}{r}0 \\
4 \\
24\end{array}$ & $\begin{array}{r}1,328 \\
200 \\
98\end{array}$ & $\begin{array}{c}\text { Trace } \\
0\end{array}$ & $7 \cdot 41$ & $\begin{array}{l}-\overline{26} \\
30\end{array}$ & $\frac{120}{68}$ & 25 & $\frac{370}{310}$ & $\frac{2,400}{2,900}$ \\
\hline 2 & $\begin{array}{r}0 \\
4 \\
17\end{array}$ & $\begin{array}{r}1,260 \\
400 \\
40\end{array}$ & & $7 \cdot 25$ & $\begin{array}{l}20 \\
28 \\
28\end{array}$ & $\begin{array}{r}230 \\
135 \\
96\end{array}$ & - & 373 & $\begin{array}{l}1,996 \\
1,681 \\
-\end{array}$ \\
\hline
\end{tabular}


plasma $\beta$-hydroxybutyrate being $730 \mu \mathrm{M}$. Plasma insulin was not measured but plasma cortisol concentration was $80 \mu \mathrm{g} / 100 \mathrm{ml}$, approximately three times the upper limit of normal.

The hyperosmolarity of these patients may be due to a rise, single or combined, of the plasma levels of glucose, urea and sodium. In our series of diabetic coma, as already stated, the glucose level was much higher and the urea level appreciably higher in patients without ketosis than in the ketotic group. In most published cases of diabetic coma without ketosis the loss of water has been proportionately greater than that of sodium so that plasma sodium levels have usually been raised, eg, to a mean level of 154 m-equiv/l in the 23 cases reviewed by Nabarro (1965). However, in our 16 cases the mean was 140 m-equiv/l (Table VI) which is within the normal range. Balance studies (Table VIII) during the rehydration of the two patients detailed in Table VII show that during the first 24 hours of treatment case 1 retained 533 m-equiv of sodium with 6.13 1 of water, ie, $87 \mathrm{~m}$-equiv $/ \mathrm{l}$, while case 2 retained 454 m-equiv of sodium with 3.521 of water, ie, $129 \mathrm{~m}$-equiv/l. Thus only in case 1 was the water loss proportionately much greater than that of sodium.

The response to insulin in this group differs from that in ketoacidotic coma. In that condition insulin resistance is the rule and relatively large doses of insulin have to be administered. The nonketotic cases appear to be more sensitive to insulin, possibly because of the lower level of plasma ketones which are insulin antagonists. It is not easy to measure insulin sensitivity during the treatment of diabetic coma, but in the two cases detailed in Tables VII and VIII the blood sugar fell rapidly from very high levels with moderate doses of insulin, 152 and 176 units respectively in the first 24 hours. In the first four hours the fall was from 1,328 to 200 and from 1,260 to $400 \mathrm{mg} / 100 \mathrm{ml}$ respectively, a mean drop of $77 \%$ as compared with $50 \%$ in ketoacidotic coma (Oakley et al, 1968), the latter figure being independent of the initial blood sugar level. A case of recovery without insulin treatment has been described (Hayes and Woods, 1968).

In the treatment of these patients with parenteral fluids it is best to give hypotonic solutions. The deficit is mainly of water and thus some such solution as half-strength saline should be given, at a starting rate of 1 to 2 litres an hour. There is, of course, no reason to give glucose solution at this stage of treatment, nor is there need for lactate or bicarbonate since there is little acidosis.

Serum potassium concentration needs to be monitored as carefully as in ketoacidosis. We suspect that when dangerous hypokalaemia results it is due to the use of very large doses of insulin (eg, Seftel and Kew, 1966). Using moderate doses of insulin in ketoacidotic coma (Oakley et al, 1968) and rather smaller doses in coma without ketoacidosis, we have not encountered dangerous hypokalaemia in spite of rapid falls of blood sugar.

The main complication of diabetic coma without ketoacidosis is arterial thrombosis, presumably a consequence of the extreme dehydration, although it tends to appear hours or days after the onset of coma. It is also seen in ketoacidotic coma, but probably less often. Two of our patients developed major arterial obstruction while apparently recovering well: in one, femoral artery obstruction was relieved surgically; in the other pulmonary artery obstruction was fatal.

The mortality in diabetic coma without ketoacidosis is reported to be as high as 40 to $50 \%$, which is much greater than in ketoacidotic coma (Oakley et al, 1968). Possible reasons are the greater age of the patients, the extremehy perosmolarity, arterial thrombosis, and delay in diagnosis. In our experience, however, the outlook is not so unfavourable. Only one of the 16 patients reported here died, a woman aged 67, not previously known to have diabetes, who died 48 hours after admission with multiple pulmonary arterial thromboses. There seems no reason why, with prompt diagnosis, rapid fluid replacement, and careful insulin therapy, better survival figures should not be obtained.

The mechanism of diabetic coma without ketoacidosis has been much discussed. The cause of the comatose state is presumably related to the intense cellular dehydration due to extreme extracellular hyperosmolality, although this may not be the whole explanation. Consciousness has been maintained in patients with a calculated plasma osmolarity of $376 \mathrm{mosm} / 1$ or more (Nabarro, 1965).

The relative lack of ketosis is presumably related to the conspicuously high blood glucose levels in these cases. Glucose has long been known to have an antiketogenic effect, hence the old suggestion that it should be administered in cases of diabetic ketoacidosis. If a depancreatized animal is given large amounts of glucose intravenously, ketonaemia disappears (Mirsky, Heiman, and Broh-Khan 1937).

The problem is why these patients develop such extreme hyperglycaemia. In some cases it is possible that the patients have consumed very large quantities of glucose-containing drinks to assuage their thirst as diabetic symptoms develop. However, not all patients give a history suggesting excessive glucose intake, and not all these patients have extremely high blood glucose levels.

We have good evidence that, unlike patients in ketoacidotic coma, these patients have some cir- 
culating insulin. Thus two of our patients had plasma insulin levels of 25 and $40 \mu \mathrm{u} / \mathrm{ml}$ respectively on admission. Consistent with this is the striking mildness of the diabetes after recovery from coma. Of the 15 survivors in our group of 16 cases, eight were subsequently treated without insulin. This is rarely possible in cases of ketoacidotic coma; in our series of 81 such cases only three were subsequently controlled without insulin. Although none of the survivors of coma without ketoacidosis has yet been shown to have recovered normal carbohydrate tolerance on full testing, at least one is on an unrestricted diet and has normal random blood sugar values. Another was shown, three and a half years after the episode of precoma, to have a fasting level of serum insulin of $59 \mu \mathrm{u} / \mathrm{ml}$ which rose to $91 \mu \mathrm{u} / \mathrm{ml}$ two hours after $50 \mathrm{~g}$ glucose by mouth. His glucose tolerance was still slightly impaired but considerable insulin secretion was preserved.

This evidence that patients in diabetic coma without ketoacidosis have some circulating insulin may mean that there is enough to prevent increases in plasma ketone and free fatty acid concentration, $i e$, ketoacidosis, but not enough to produce a significant effect on glucose uptake. A dissociation between the effect of small amounts of insulin on the uptake of glucose by forearm tissue and the output of nonesterified fatty acids has been demonstrated by Zierler and Rabinowitz (1964) and this could provide an explanation for the apparent paradox of diabetic coma without ketoacidosis. The distinction between the two types of diabetic coma does not appear to be based on individual constitutional differences. We have records of a man who, nine months after an episode of coma without ketoacidosis, was admitted in typical ketoacidotic coma with a plasma bicarbonate level of $2 \mathrm{~m}$-equiv/1 (Oakley et al, 1968).

A very similar syndrome has been described in patients with severe burns, when gross hyperglycaemia, dehydration, and coma without ketosis appear during the recovery phase, one to three weeks after admission. Blood glucose rises rapidly to $\mathbf{8 0 0}$ to $1,700 \mathrm{mg} / 100 \mathrm{ml}$. In one carefully studied case (Rosenberg, Brief, Kinney, Herrera, Wilson, and Moore, 1965) there was intense glycosuria, the plasma osmolarity was $459 \mathrm{mosm} / \mathrm{l}$, and blood $p \mathrm{H}$ 7.38. Urinary and blood ketones levels were normal. This patient regained consciousness and recovered when given insulin and large amounts of intravenous fluid. Four months later, however, he again became diabetic and although he then improved without insulin or drug treatment, glucose tolerace was still abnormal on oral and intravenous testing one year later. Of five other reported cases of hyperglycaemia and coma after burns two survived with a return of glucose tolerance to normal in two to six months (Rosenberg et al, 1965). Two of the three deaths were probably due to the hyperglycaemic syndrome itself.

This syndrome is clearly different from the mild or moderate hyperglycaemia that may be seen directly after burns, shock, injury, surgical operation, or myocardial infarction. In the patients in whom coma, hyperglycaemia, and dehydration appeared after burns very high carbohydrate diets were being given and this may eventually have overwhelmed the pancreatic $\beta$-cells. When carbohydrate intake was reduced, blood levels returned to normal; later when it was again increased from about 200 to $400 \mathrm{~g}$ daily, hyperglycaemia returned. Plasma insulin determinations have not been reported in these cases. This syndrome seems to be akin to the diabetic coma without ketoacidosis which we have been discussing. We can surmise that unconsciousness in this condition is at least partly due to cellular dehydration resulting from hyperglycaemia, caused by a state of relative but not total insulin deficiency from which partial recovery is possible.

The characteristic features of the syndrome of diabetic coma without ketoacidosis are therefore (1) that it usually occurs in older people who may not previously have been known to be diabetic; (2) that patients are relatively insulin-sensitive; and (3) that after recovery the diabetes may be mild and insulin treatment may not be needed.

I am grateful to Drs J. G. Salway, M. G. FitzGerald, P. J. Watkins, B. J. Freedman, D. M. Hill, I. D. Ramsy, T. C. Harvey, D. Williams, M. Berry and K. W. Taylor, for generously giving me access to their unpublished material and allowing me to quote from it.

\section{REFERENCES}

Atchley, D. W., Loeb, R. F., Richards, D. W., Jr., Benedict, E. M. and Driscoll, M. E. (1933). J. clin. Invest., 12, 297.

Bergmeyer, H. U., and Bernt, E. (1965). Enzym. Biol. Clin., 5, 65.

Clements, R. S., Jr, Prockop, L. D., and Winegrad, A. I. (1968). Lancet, $2,384$.

Dreschfeld, J. (1886). Brit. med. J., 2, 358.

Ehrlich, R. M., and Bain, H. W. (1967). New Engl. J. Med., 276, 683. FitzGerald, M. G., O'Sullivan, D. J., and Malins, J. M. (1961). Brit. med. J., 1, 247.

Hayes, T. M., and Woods, C. J. (1968). Lancet, 1, 209.

Hoff brand, B. I., and Sevitt, L. H. (1966). Ibid., 1, 402.

Houssay, B. A., Rietti, C. T., Ashkar, E., Del Castillo, E. J., Galli, M. E., Roldán, A., and Urgoiti, E. J. (1967). Diabetes, 16, 259.

Johnson, R. E., Sargent, F., II, and Passmore, R. (1958). Quart. J. exp. Physiol., 43, 339.

Mirsky, I. A., Heiman, J. D., and Broh-Khan, R. H. (1937). Amer. J. Physiol., 118, 290.

Nabarro, J. D. N. (1965). In On the Nature and Treatment of Diabetes (Excerpta med. int. Congr. Ser. no. 84), edited by B. S. Leibel and G. A. Wrenshall, p. 545. Excerpta Med. Foundation, Amsterdam.

Spencer, A. G., and Stowers, J. M. (1952). Quart. J. Med., 21, 225. 
Oakley, W. G., Pyke, D. A., and Taylor, K. W. (1968). Clinical Diabetes and Its Biochemical Basis, p. 420 et seq. Blackwell, Oxford.

Rosenberg, S. A., Brief, D. K.. Kinney, J. M., Herrera, M. G., Wilson, R. E., and Moore, F. D. (1965). New Engl. J. Med., 272, 931.

Schwartz, T. B., and Apfelbaum, R. I. (1966). Yearbook of Endocrinology, 1965-66, p. 165. Year Book Medical Publishers, Chicago.
Seftel, H. C., and Kew, M. C. (1966). Diabetes, 15, 694.

Watkins, P. J., and FitzGerald, M. G. (1968a). Ibid., 17, 398.

Werk, E. E., Jr, and Knowles, H. C. Jr (1961). Ibid., 10, 22.

Williamson, D. H., Mellanby, J., and Krebs, H. A. (1962). Biochem. J., 82, 90.

Young, E., and Bradley, R. F. (1967). New Engl. J. Med., 276, 665.

Zierler, K. L., and Rabinowitz, D. (1964). J. clin. Invest., 43, 950. 